\title{
Intercultural Interaction of the Volga Region Nations in the Context of Ethnomusical Traditions
}

\author{
Nelya Khabibullovna Nurgayanova, Gulnara Ibragimovna Batyrshina \\ and Lidiya Alekseevna Ahmetova
}

Kazan (Volga Region) Federal University, Russian Federation, 420008, Kazan, Kremlyovskaya St., 18

DOI: http://dx.doi.org/10.13005/bbra/1963

(Received: 02 August 2015; accepted: 18 September 2015)

\begin{abstract}
Each nation, due to its social pattern, created its peculiar traditions, acting as specific memory, fulfilling the functions of preservation, development and translation of cultural and spiritual values, moral and aesthetic consciousness, playing an important role in the formation process of polymathic and spiritually developed personality. Being an important component of not only national, but also universal culture, various types of folklore creativity, holidays, customs and traditions determine moral and aesthetic potential of each ethnic group. Ethnomusical traditions present the huge intellectual richness and inexhaustible source of folk wisdom; they act as a system of national and aesthetic values, providing an opportunity to develop the spiritual needs and cognitive interests of the younger generation. At present, the problems of interaction and dialogue of ethnic cultures become of great importance; their participants are able to understand and accept each other, not imposing their own worldview and traditions. The article deals with the process of intercultural interaction and mutual enrichment of indigenous people of the Middle Volga in the context of development of their ethnomusical traditions. Centuries-long history of development of the Volga region ethnomusical traditions is a bright evidence of contradictive, but regular period of formation of many-sided ethnic musical culture of the region, reflecting, on the one hand, the diversity of each of these ethnic groups, living in its territory, and on the other hand, accumulating and directing the creative energy of the Volga region people in keeping with the all-Russian artistic tradition. Based on the results of folklore expeditions along the territory of the Republic of Tatarstan, at present, the authors of the article make a conclusion about the prospectivity of functioning of ethnomusical creativity in cultural and educational space, as a factor of intercultural interaction of the Volga region nations.
\end{abstract}

Key words: Intercultural interaction, cultural dialogue, ethnomusical traditions, folklore, Volga region nations.

Cultural and historical development of the modern world takes place in polyethnic, polyconfessional and multicultural conditions. At present, interethnic relations have come to the fore of the social life, and the search for new forms of optimal cooperation of nations, the study of experience of international communication,

\footnotetext{
* To whom all correspondence should be addressed.
}

interethnic tolerance have become the most relevant problems. The challenging task of the present day is to set people free from the ethno-centrist views and to direct them to the necessity of integration, when the diverse cultures, joined into one community, have the right to preserve their individuality and ethnic identity.

Each nation is being formed in the course of centuries-long history, and its ethnic identity, national traditions, spiritual experience are being formed into unique local culture, where the original 
features are harmonically combined with the universal human values. However, each culture does not exist in itself, but only in interaction with the others, at that, the interacting process has the mutually conditioned, double-sided character, when the change of the state, content and functions of one phenomenon is always accompanied by the changes in another one. Intercultural interaction, understood in the same way as the "dialogue of cultures", is the mutual understanding of the participants of this process and, at the same time, preservation of their own opinion: "penetration into the other one (merging with him) and keeping the distance (your own place). Foreign culture is being uncovered deeply and thoroughly only in the eyes of another culture" (Stolyarova, 2004, p. 34-35).

In the center of our attention is the intercultural interaction of ethnomusical traditions in polyethnic environment of the Middle Volga region, one of the unique multinational regions of Russia, where the ethnocultural traditions of Slavonic, Finno-Ugric and Turkic nations existed for many centuries; the interpenetration and mutual enrichment of their spiritual, material, cultural, social, interconfessional and ethnopedagogical experience took place; the traditions of good neighborly interethnic relations were formed. At that, it is necessary to mention, that the indigenous people of the Volga region - the Tatar, the Russian, the Mari, the Mordva, the Chuvash, the Udmurt were always located in one living space, practically without the state ethnic boundaries. Conventional frontier lied in confessional neighborhood of Islam, bearing the Muslim artistic traditions, and Christian Religion, in combination with some preserved forms of pagan ritualism.

A long period of contacts and cooperation predetermines the significant intercultural interaction. Modern scientific knowledge tends to consider the Volga region as an integral region. Thus, relatively this theory, the ethnographers use the notion "the Middle Volga historical and ethnographic area", that allows speaking about the unity of civilization space, where, alongside with the compact resettlement of separate ethnic groups, there are the regions, and even some settlements, where the representatives of several nationalities, different in language and culture, intercross and live together from of old
(Busygin, 1984, p. 5).

Speaking about the specificity of such cultural interaction, it is necessary to pay attention to the special ethnic unit, where it is possible to see a special geographic pattern of Eurasian brilliance, denoted in musicology as "the VolgaUral musical civilization” (Radzetskaya, 2013, p. 71-72). In this aspect, the scientists of the region carried out the ethnomusical studies, among which it is possible to distinguish the following works: "Concerning general components of musical and poetic systems of the Volga region and Cisurals" by M.G. Kondratyev (Kondratyev, 1999) and "Traditional musical instruments of the Volga-Ural region” by V.I. Yakovlev (Yakovlev, 2001). The same significant musicological works, devoted to traditional musical culture of ethnic groups of the Volga region, were created by Yu. A. Ilukhin (Ilukhin, 1961), N.I. Boyarkin (Boyarkin, 1983), O.M. Gerasimov (Gerasimov, 1996), R.A. IskhakovaVamba (Iskhakova-Vamba, 1997), Z.N. Saydasheva (Saydasheva, 2002), M.N. Nigmedzyanov (Nigmedzyanov, 2003), N.Yu. Almeeva (Almeeva, 2012) and others. The significant contribution to the study of the singing culture of nations of the Volga-Kama region was made by the expedition of Hungarian scientists Laslo Vikar and Gabor Bereczki (Vikar \& Bereczki, 1999).

\section{METHODS}

System and structural analysis of cultural, musicological, folklore and educational researches; generalization of proper and advanced pedagogical experience within the framework of the problem researched.

\section{Materials}

The region has accumulated a colossal general layer of culture of the Volga region ethnic groups, with rich artistic-aesthetic and ethnopedagogical potential; their folklore heritage faces kindred shades.The premier researchers of the musical cultures of the Middle Volga region L.V. Brazhnik and A.L. Maklygin, providing a comparative characteristics of musical language of the region's nations, point out, that the single base of musical content of cultures of these ethnic groups is pentatonism. Thus, L.V. Brazhnik states, that "being the essential feature, ahemitonic (nonsemitonal) intonation pattern unites musical 
cultures of the region into integral musical and language conglomerate. Regional interethnic musical language is the language of ahemitonics; it belongs to the number of most organic features of the commonness of nations of the Volga region and Cisurals” (Brazhnik, 2002, p. 219). A.L. Maklygin finds the similar musical features of nations of the Middle Volga region in relative proximity of genre systems of song folklore, as a part of folk instruments, in monodic principle of musical thinking, defining it as "a natural form of national sound expression” (Maklygin, 2000, p. 8).

In the sphere of study of traditional musical culture, quite vast factual material was accumulated as a result of numerous expeditions; it shows, that the original and unique ethnomusical traditions, being the basis for preservation and development of culture of each nation from the earliest times, had been initially developed in varied vocal genres. The art of singing, presenting the inseparable synthesis of music and word, being the most democratic and accessible way of artistic creativity, having the ability to express the finest human emotional feelings, hopes and aspirations, constitute the largest and most valuable component of cultural heritage of nations of the Volga region. Labor, family-ceremonial chants performed the educational and upbringing functions; moral values were strengthened through the acquaintance with the musical-epic genres, among which are the Tatar baits, the Mordovian kuvaka morot, the Chuvash historical songs and ballads "peyetsem” (Kondratyev, 2007, p.75). The main differences in development of singing traditions are mainly conditioned by the confessional influence on the spiritual culture of these nations. Muslim customs contributed to the development of Tatar musical-poetic genres, resulting in the blossom of bookish melo-declamation and the appearance of subtle forms of monodic singing with its unique performing phenomenon "mon". Pagan ritualism influenced much on the creativity of other nations of the region, that is why the traditions of collective vocal singing, based on rhythm-timbre thinking, were preserved.

M.G. Kondratyev (Kondratyev, 1999) distinguishes the following region-wide components of musical-poetic systems of the Volga region:

1. Some genre varieties of songs and their names. The scientist provides the most widely used terms, as examples: nardugan yurry (Chuvash) - the songs of the New Year festive ceremony, nardugan (Chuvash, Tatar, Udmurt), nardava, nardvan (Mordovian-Erzya, Moksha), seren yurry (Chuvash) - the songs of the spring cathartical ceremony, seren (Chuvash), seren (tatar), surem (Mari), suren (Udmurt); khana yurry (Chuvash) - the guest song, khana (Chuvash), kunak (Tatar), kuno (Udmurt), una (Mari) - a guest; takmak dance chants of the Chuvash, the Tatar, the Udmurt, the Mordva, the Mari.

2. Ahemitonic pentatonism is a tonal system, constituting the basis of folk song of the Tatar, the Chuvash, the Mari, and mainly of the Mordva and the Udmurt. At that, the author points to its ethnic identity: the fairness of the K.V. Kvitky's remark, that the Tatar of the Volga region preserved the ahemitonic pentatonism in purest view, than the Chinese"; he points out, the Chuvash pentatonism is notable for the variety of combined forms; the peculiarities of ahemitonic pentatonism of the Mordva music are shown in polyphonic context; the Mari singing culture has the tune-soundrow identity, connected with the quarttertian tunes, different from pentatonism in their structure.

3. A special type of rhythm - quantitative, met in the songs of the Chuvash, the Udmurt, the Tatar, the Mari. M.G. Kondratyev points out, that the finest forms of quantitative rhythm were preserved in traditional songs of the Chuvash and the Tatar. The quantitative rhythmic of the Mari and the Udmurts is as if "overlaid" the other archaic forms of rhythmic organization.

4. A special type of plot composition - short plot, or aphoristic plot, typical of the songs of the Chuvash, the Tatar, the Mari and the Udmurt.

5. A special type of song form - many-syllabic with asymmetrical cesura, which is found in the folklore of the Chuvash, the Tatar, the East Mari and the South Udmurt. The scientist points out that in Tatar plangent songs, this song form, being as if veiled by 
chants and additional vocalization, is revealed by means of analysis; in Udmurt, it is frequently combined with the other forms, typical of the national melodiousness. It is characterized by the syllabic scheme: $6(7)+46(7)+4(3)$; five-cell rhythmic structure; strophic composition consists of two contrast musical structures (AB), the repetition of the second structure is typical (ABB, sometimes ABBB).

The traditional musical instruments present an integral component of the ethnomusical culture. From the earliest times, acting as a part of national traditions, the construction, tonal-acoustic and artistic-performing opportunities of the musical instruments reflected the historical, naturalgeographic, sociocultural living environment of ethnic groups.

Musical instruments of the Volga region nations are notable for the rich diversity and multifunctionality; they bear the artistic-aesthetic, emotional-psychological, signal-communicative, magic, ceremonial, educational and other elements.

The investigators O.M. Gerasimov (Gerasimov, 1996), G.M. Makarov (Makarov, 2006), V.I. Yakovlev (Yakovlev, 2001) and others reveled and described more than hundred names of traditional musical instruments of the Middle Volga region, which involve idiophonic (idiophones), band (aerophones), membrane (membranophones), string (chordophones). Some instruments gained currency in the representatives of many ethnic and local groups, the others belonged only to one nation.

Among the numerous wind instruments, met in all the nations of the Middle Volga, the most common are the vertical flutes, which the Tatar name kurai, the Chuvash - shakhlich, the Mari shiyaltysh, the Mordva - sendien morama, the Udmurts - uzygumy.

Many Volga region people know a very old fretted instrument, where the sound is produced by plucking the chords, - gusli, which the Tatar named gesle, the Chuvash - kesle, the Mari-kyusle, the Mordva - gusli, kayga, the Udmurt -krez.

One of the favorite and best-loved musical instruments of the Volga region is balalaika. The Tatar name the instrument of such type as dumbra, the Chuvash - tumra, the Mari - tombyra, the Udmurt - dombra.

The group of idiophones involve the instruments, where th source of sound is the material itself, from which they or their sounding detail are made. The plucked subgroup is of peculiar interest; trump harp, which the Tatar name kubyz, the Chuvash - varkhan, kupas, the Mari - umsha kovyzh, the Udmurt - zubanka, umkres, the Mordva - varganchik.

Alongside with the genesis study, the scientists created a scientific base to substantiate the processes of interaction and mutual influence in musical instruments of the Volga region people, explaining such relationship by the historical circumstances, where each ethnic culture, being in face-to-face interaction, was formed. V.I. Yakovlev finds the reflection of both general and particular ethnic peculiarities in appearance and distribution of traditional music instruments: "All this is the consequence of such processes, as ethnoinstrumental, ethnocultural integration and differentiation, ethnocultural convergence, longstanding interethnic interaction of nations, different in languages, within the boundaries of the Volga-Ural historical and ethnical region" (Yakovlev, 2001, p. 3-4).

\section{RESULTS}

Close neighborhood of nations of the Middle Volga region in conditions of interethnic cultural relations contributed to the speech multilingualism, when the habitants of one village, as a rule, can speak the languages of their neighbors, and, consequently, know their customs, songs and dances. In the village festivals, it was considered a good style to bring a new song, heard in the ethnic neighbors (Maklygin, 2000, p. 37).

Under this investigation, the samples of intercultural interaction found the reflection in the territory of the Tatarstan Republic, included to the Middle Volga region, where, the same as in whole Russia, Russian is the language of international communication. Thus, for instance, during the folklore expedition in the period from 2014 to 2015, it was revealed, that in the Chuvash, Mari and Udmurt villages of the Republic, many habitants speak not only the native language quite well, but also Tatar, and know folklore chants and instrumental folk-tunes of their nation, as well as 
of Russian and Tatar. The representatives of local ethnic group of Kryashen Tatar demonstrated the acquaintance with language and singing traditions of the Lower Chuvash. In the course of study of the functioning process of ethnomusical traditions in the nations of the Volga region in Kaybitsk district of the Tatarstan Republic, the authors revealed the melodies and chants, equally met in different ethnic groups, the representatives of which pointed the belonging of the studied musical instruments exactly to their nation. One of such examples is the old folk round-playing chant "Zalida”, which was written in Tatar village Burunduki, where the Muslim Tatars live; then, this chant, but in Chuvash language, was found in the village Malye Memi, then this situation was repeated in the village Old Tyaberdino, where the main ethnic group is the Krayshen Tatar (Christian Tatar). One more sample is the Russian folk song "We have a Saturday today". In the village Rodniki of the Aleksyevsk region of the Tatarstan Republic, this song has the same melody, but it is in Mordovian language, at that, the village habitants state, that initially it was a Mordovian folk song.

The commonness of ethnic cultures of the Tatar, Chuvash, Mari, Udmurt and Russian nations in the territory of the Middle Volga region is proved by their rituals and holidays, connected with their work practice, and preserved during many centuries. The holidays of the folklore of these ethnic groups have the functional and typological similarities; the holidays are the mass actions, playing a great aesthetic role in the life of nations. For instance,the largest agricultural holiday of the Tatar nation is "Sabantuy" - the holiday, devoted to spring sowing. The holidays of neighboring nations have the typological similarity. It is known, that the Chuvash have "Akatuy" - a plough wedding, the Mari have "Aga-Payram" - a plough holiday, the Udmurt have "Gyron bydton" - a holiday, when the spring field works finish, the Mordva have "Keret ozks" - a plough praying (Sharafutdinov, 2004, p. 149). These holidays take place in the open air, in the picturesque place not far from the village. Horseracing, running competitions, different games took place there; the musicians got the opportunity to show their creative abilities. There are the regularities, and one of them is the centuries-long living of nations close to each other in one regional territory.

\section{DISCUSSION}

The humanity has accumulated the richest artistic traditions, which, being passed on from the generation to generation, played a significant role in the development of personality. Musical folklore, presenting an important factor of upbringing and provision of the young generation with the information about the surrounding world, playing an exclusive role in the development of personality, always took a significant place in the vast structure of folk traditions. Being in contact with them, a child, from the early age, gets a concept of the beauty, assimilated definite ethic and aesthetic values, everyday and moral behests.

That is why, the acquaintance with ethnomusical traditions plays an important role in formation of culture of personality in the educational process, as in the process of its historical development, the musical culture of its nation constantly accumulated spiritual, moral and aesthetic values of great pedagogical potential. It is shown in the works of scientists, workers of culture and art, who see possibilities to solve the problems of interconfessional communication, tolerance and morality in the educational system. Numerous investigations on ethnopedagogics (G.N. Volkov (Volkov, 2004), L.P. Karpushina (Karpushina, 2009), F.Sh. Salitova (Salitova, 2008), Z.M. Yavgildina (Yavgildina, 2002) and others.) consider great spiritual-moral potential, infinite possibilities of traditional ethnic cultures, as a specific phenomenon in general variety of world civilization.

The works of S.V. Karkina (Karkina et al., 2014), A.N. Valiahmetova (Valiahmetova et al., 2014), R.A. Fahrutdinova (Fahrutdinova et al., 2014) and others state, that all-round acquaintance with traditions of different nations contribute to integration with other cultures, upbringing of positive relation to them.

E.V. Kovrikova writes: "Penetration into spiritual origin and traditions of world musical culture, the analysis of their intercultural interaction in the aspect of modernity, brings up the respect for the identity of each nation and its values, gives rise to compassion feelings, perception of commonness of cultures and people, and also acquisition of skills of their positive 
communication” (Kovrikova, 2010, p. 287).

N.K. Nurgayanova states, that the focus of upbringing on perception and understanding of musical styles in the context of spiritual culture of different religious traditions in the process of communicative interaction (the performer - the intonation means - the percipient) results in intercultural and interconfessional dialogue, the appearance of the focus on tolerant relation to another ethnic traditions and culture (Nurgayanova, 2012, p. 154).

In the opinion of G.R. Stolyarova, education and enlightenment in whole break the boundaries of interethnic misunderstanding, detachment and prejudicialness. Actually, wide awareness removes many fears and prejudices against "foreign" cultures, contributes to the understanding, that each culture, with all its strange external expressiveness, is based on universal human values and views (Stolyarova, 2004, p. 105).

In the development of forms and genres of oral musical creativity of all nations, it is regular, that in the course of historical development, they evolve into stable musical and pedagogical traditions, which always presented the basis to form moral and aesthetic ideals, worldview of the personality (Salitova, 2008, p. 30).

Thus, the study of ethnomusical traditions in the context of intercultural dialogue, historical and pedagogical analysis of the main circle of folklore genres, musical instrumentarium and folk holidays provides an opportunity to speak about widest instructional and educational possibilities of folk culture in development of international spiritual bonds, upbringing of tolerance, preservation of social stability, extension of competence in the problems of intercultural interaction.

\section{CONCLUSION}

Various artistic traditions were formed in the development process of ethnic groups, taking a leading place in formation of polymathic and spiritually developed personality.

A tradition is an important block in the cultural system of the ethnic group. It is a cementing agent, a distinctive feature of the specific nation. It changes color and reflects practically all main sides of life. Traditional actions throw the light on the complex problem of ethnogenesis, reflects the historical connections and spiritual commonness with other nations. They reflect separate problems of dwelling, folk knowledge, mythology, art and believes. However, the traditions have another side, quite more important: they present a powerful instrument for national upbringing and cohesiveness of nation into one spiritual unity. Mutual acquaintance of ethnic groups with the information about each other shall be considered as the dialogue of cultures, coming to the level of modern politics.

The study of problems of development and interaction of spiritual values of ethnic traditional cultures, possessing principal equivalence and equipollence, provides a possibility to reveal specific peculiarities and to detect common things to reconstruct more full picture of historical development and variety of world civilization.

\section{Gratitude}

This article was written within the framework of the scientific project \# 14-16-16006 supported by the Russian Foundation for Humanities [RFH] and government of Tatarstan.

The work is performed according to the Russian Government Program of Competitive Growth of Kazan Federal University.

\section{REFERENCES}

1. Almeeva, N.Yu., The Kryashen Tatars'songs. The $2^{\text {nd }}$ issue. Molkeevsk group. St.-Petersburg - Kazan: Contrast Publisher, 2012.

2. Boyarkin, N.I., Mordovian folk musical art. Saransk: Mordgiz, 1983.

3. Brazhnik, L.V., Stylistic tendencies in development of professional musical cultures of the Middle Volga region and Cisurals. Regionology, 2002; 3: 219-224.

4. Busygin, E.P., and Zorin, N.N., Ethnography of nations of the Middle Volga region. Kazan: Publishing House of the State University, 1984.

5. Fahrutdinova, R.A., Fahrutdinov, R.R., and Konopatskaya, E.A., Formation of general cultural competencies of students in the educational space of the University. Life Science Journal, 2014; 11(6): 525-529. Retrieved from http://www.lifesciencesite.com. 76

6. Gerasimov, O.M., Folk musical instruments of the Mari. Ioshkar-Ola: the Ministry of Culture of the Mari El Republic. A Center of Folk 
Creative Work, 1996.

7. Ilukhin, Yu.A., Musical culture of the Chuvash. Chuvash folk music. Cheboksary: Chuvash Book Publisher, 1961; 1.

8. Iskhakova-Vamba, R.A., The Tatar Folk Musical Art (Traditional Folklore). Kazan: Tatar Publishing House, 1997.

9. Karkina, S.V., Khabibulina, L.F., and Khurmatullina, R.C., Approach to a cultures' dialogue in the musical and aesthetic education of undergraduates. Life Science Journal, 2014; 11(10s), 296-299. Retrieved from http:// www.lifesciencesite.com. 53

10. Karpushina, L.P., Conceptual bases of ethnomusical education of pupils in general education institutions. Integration of education, 2009; 2: 71-74.

11. Kondratyev, M.G., Concerning general components of musical-poetic systems of the Volga region and Cisurals. Musical Science of Middle Volga Region: Results and Perspectives, 1999; 59-64. Kazan: Kazan State Conservatory.

12. Kondratyev, M.G., Chuvash music: from mythological times up to formation of modern professionalism. Moscow: PER CE, 2007.

13. Kovrikova, E.V., Some problems in training of future teacher of music for the activity in polycultural society. A Reporter of Tatar State Humanitarian-Pedagogical University, 2010; 4(22): 285-289.

14. Makarov, G.M., Traditional wind instruments of the Tatar of Volga-Kama region (The problems of genesis and historical reconstruction). Kazan: Institute of Language, Literature and Art, named by G. Ibragimov, 2006.

15. Maklygin, A.L., Musical cultures of the Middle Volga region: the formation of professionalism. Kazan: Kazan State Conservatory, 2000.

16. Nigmedzyanov, M.N., Tatar folk music. Kazan: Magarif, 2003.

17. Nurgayanova, N.K., Pedagogical potential of singing traditions of the Tatar nation. Scholarly
Notes 2012: a Collection of Scientific Articles of Teachers of the Institute of Philology and art of the Kazan Federal University, 2012; 151154. Kazan: Kazan University.

18. Radzetskaya, O.V., Musical projections of the cultural dialogue between East and West in the context of the Volga-Ural civilization. FinnoUgric World, 2013; 1: 71-75.

19. Salitova, F. Sh., Musical and pedagogical traditions of the Tatar people. Kazan: Publishing House of the Tatar State Humanitarian and Pedagogical University, 2008.

20. Saydasheva, Z.N., Singing culture of the Tatar of the Volga-Kama region. Evolution of genrestylistic forms in the context of national history. Kazan: Matbugat Yorty, 2002.

21. Sharafutdinov, D.R., Historical roots and development of traditional culture of the Tatar nations in the XIX-beginning of the XX centuries: a monograph. Kazan: Gasyr, 2004.

22. Stolyarova, G.R., A phenomenon of interethnic interaction: the experience of post-Soviet Tatarstan. Kazan: Publishing House of the Kazan University, 2004.

23. Valiahmetova, A.N., Salpykova, I.M., and Nurgayanova, N.K., Music teacher to-be tolerance formation in the multicultural educational environment by means of musical art. Life Sci J, 2014; 11(9): 396-400. Retrieved from http://www.lifesciencesite.com. 63

24. Vikar, L., and Bereczki, G., Tatar folk songs. Budapest: Akademiai Kiadd, 1999.

25. Volkov, G., Ethnopedagogics. Moscow: Tsentr Akademia, 2004.

26. Yagvildina, Z.M., Musical and aesthetic education of younger students: Theory and Practice. Kazan Publishing House of the Kazan University, 2002.

27. Yakovlev, V.I., Traditional musical instruments of the Volga-Ural region. Historical-ethnographic study. Kazan: Publishing House of the Kazan University, 2001. 